\title{
ADVANTAGES AND DISADVANTAGES OF DRG SYSTEM FOR TURKEY
}

\section{Haşim ÇAPAR ${ }^{\star, \dagger}$}

Department of Health Management, Faculty of Health Sciences, Istanbul Sabahattin Zaim University, Istanbul, Turkey

DOI: https://doi.org/10.15520/ijmhs.v9i2.2441

Accepted 18 Feb 2019; Received 28 Jan 2019; Publish Online 28 Feb 2019

\author{
Reviewed By: Dr. \\ Daniel V. \\ Department: Medical
}

\begin{abstract}
Since the number and amount of health services tried to be given in health institutions cannot be measured, it cannot be charged as the remuneration of services in other sectors. For this reason, health services should be evaluated, coded, and grouped on the basis of disease, and should be charged within the framework of these codes and groupings. In the light of all these evaluations, the aim of this study is to provide a fair and quality distribution of the health services provided to the community, to provide a fair reimbursement system to the health service providers in return for the health services provided and to provide the maximum quality, the least cost of the health services provided and the reimbursement in health institutions. Diagnose Related Groups (DRGs) system. One of the most important issues in the DRGs system is the process of determining costs clearly, accurately, objectively and up-to-date. This process should be determined not only by hospitals but by the participation of all stakeholders in health services.
\end{abstract}

Key words: Hospital-DRGs (Diagnosis Related Groups)-Reimbursement SystemCost

\section{INTRODUCTION}

Health institutions are one of the specialized institutions in which health care services are provided and health care and specialization is diversified. In this context, it is necessary to perform the effective presentation of health services, to provide the necessary financing for the provision of health services, and to determine the performance standards and criteria of the health manpower at the individual and social level. Without compromising clinical quality, using resources effectively to measure health outcomes and outputs and manage these processes is a complex process. Fair and equitable provision of health services as delivered by health institutions in Turkey are required to provide a refund. In order to achieve individual and institutional performance and quality increase in health institutions and to eliminate unnecessary health services costs, studies are carried out to define the diseases, group the defined diseases and make repayments accordingly.

Since the number and amount of health services tried to be given in health institutions cannot be measured, it cannot be charged as the remuneration of services in other

* Corresponding author.

$\dagger$ Email: hasim.capar(at)izu.edu.tr. sectors. For this reason, health services should be evaluated and coded and grouped on the basis of disease, and should be charged within the framework of these codes and groupings. Therefore, it is very difficult to determine the health services and to determine the amount of reimbursement of health services. In addition, the amount of effect in the codes and groups belonging to the health services classified by certain codes and groups can never meet the actual effect amount. This is an indication of the fact that the classification and classification of health services can be successful if dealt with in a value-based manner.

Considering all these evaluations, it is necessary to make a fair and quality distribution of the health services provided to the community and to provide a fair reimbursement system to the health service providers in return for the health services provided and the way to provide the health services with the maximum quality and the least cost. It can be stated that this pathway is the Diagnose Releted Groups (DRGs) system, which is a way out to solve problems related to reimbursement in health institutions.

The objective of this study, a new reimbursement system model as presented in the DRGs system is to make recommendations to Turkey by examining the advantages and disadvantages. 


\section{Diagnosis Releted Groups (DRGs)}

A cost arises as a result of the services provided in health institutions. Health care providers are reimbursed to cover these costs incurred as a result of the provision of health services $[1,2]$.

Health services, because of their distinctive features are different from other goods and services, the costs of the services provided by the health service providers. The costs incurred for the health services undertaken by the health care providers are billed and then collected from the individuals or individuals from which they belong [3] .

Nowadays, different reimbursement methods are used in order to calculate a fair cost of health service providers who provide health care services to the insured patients and the pricing of reimbursement systems in the pricing of modern health services and reimbursement systems [4-6] .

Although the reimbursement systems differ, the main objective of all is to ensure the provision of health services in a equitable manner and to improve the quality of health services by reducing health expenditures. In addition, sustainability of health services financing, transfer of resources allocated for health services to the right areas and obtaining the expected performance from health systems are also important objectives of reimbursement systems [7, 8] .

Diagnose Related Groups (DRGs), which claims to be able to accomplish all of these goals, has been actively being used since 1983 in many countries such as United States of America, Australia, Canada, Romania and Singapore [7, 9]

Robert Barcley and Jhon D. Thopmson, whose main objectives are to create a reimbursement system with effective and efficient resource utilization strategy by making patient classification, classify patients and diseases according to certain characteristics and establish a better quality and less costly reimbursement system $[4,10,11]$.

This reimbursement system was called Diagnose Releted Groups (DRGs) and translated into Turkish Diagnosis Associated Groups (DAGs). To achieve the stated objectives, a grouping is carried out taking into account DRGs, hospital cases, diagnoses for disease classification and procedures performed by health service providers and is designed as a reimbursement model according to this grouping [2, 11-14]

\section{Objectives and Advantages of DRGs System as a} Reimbursement System

The main objective of the DRGs system is to create a systematic process to ensure that repayments from insurance companies that provide financing on behalf of individuals or individuals in return for the health services offered by health care providers are provided in a fair and equitable manner and to ensure the continuity of this systematic process $[2,14,15]$.

It is one of the main objectives of the DRGs system to ensure that the resources allocated for health services are used in the right place, in the right amount and at the right time, and to avoid unnecessary and extra use of the resources allocated for health services by increasing both individual and corporate performance [16] .
Another important objective of the DRGs system is to provide effectiveness and efficiency by ensuring the efficiency of allocation of resources allocated for the financing of health services as well as ensuring effectiveness and efficiency [17] .

The production and distribution of health services is only one aspect of the DRGs system. For this reason, another important aspect of the DRGs system is the provision of health services in the desired characteristic and quality [2, $18]$.

DRGs is a reimbursement system that aims to determine the costs of services provided in health institutions in a realistic way, to define the inputs and outputs of health institutions and accordingly to reimburse the service providers [3, 19] .

The DRGs was developed to facilitate the delivery of health services in hospitals, and to standardize budgeting, cost and quality control for the continuity of health services provided [14, 19] .

After determining the main objectives of the DRGs system, it is very important to list the advantages of presenting this system as a model for reimbursement of health services. For this purpose, the advantages of DRGs system in terms of health services can be listed as follows $[2,7,14-16,18,19]$

- A measurable definition of the services provided in health institutions,

- Accurate calculation of the costs of the services provided in health institutions,

- Ensuring an objective assessment of the performance of people working in health institutions,

- Ensuring transparency in the payment system with the identification of products and outputs,

- Ensure that the areas where resources need to be allocated are correctly identified,

- Providing evidence-based decisions of the hospital administration;

- To increase the technical and allocation efficiency of resources by preventing unnecessary services,

- Classification of health services by making the classification and pricing of the services given accordingly,

- To improve the quality of care,

- To reduce the average length of stay in hospitals,

- Ensuring effective, efficient and fair use of resources,

- To ensure performance improvement.

Considering the above advantages of the DRGs system, it can be stated that there are many advantages. However, it can be misleading to say that the DRGs system is a good payment system based solely on its advantages. Therefore, the disadvantages of the DRGs system will be given in the following section. In this way, the advantages and disadvantages of DRGs system will be discussed together and a more logical and correct result will be tried.

Disadvantages of DRG System as a Reimbursement System

In the context of this study, the advantages of DRGs system were discussed in the previous section and the disadvantages of DRGs system will be discussed in this section. 
Disadvantages of DRGs system in terms of health services can be listed as follows $[2,7,14-16,18,19]$.

- Increasing general and repeated applications to hospitals,

- The tendency to write extra code to hospitals due to repayments via codes,

- Difficult to identify products and outputs

- It is not easy to classify the products and services due to the special features of health services,

- It is not desirable to choose the hospitals and physicians who prefer the procedures with low weight due to the repayments of the products and outputs.

- Patients are under-served,

- Less use of resources,

- To increase the costs of physicians and hospitals to increase the costs of procedures with less relative value in order to maximize their interests,

- Physicians try to identify patients as sensitive to charges. In other words, the physician chooses the categories with the highest wages, so that they can maximize their interests,

- Physicians try to select patients who are less likely to handle patients according to their performance returns. Because reimbursements to health care providers are based on diagnosis, not treatment-based. In this case, physicians give up the quantity and quality.

- Restrict access to services requested by more complicated and advanced expertise.

As can be seen, it is clear that the DRGs system has both advantages and disadvantages but it has strong advantages over its disadvantages. Moreover, only a fraction of the disadvantages in all other reimbursement models in health care apply to the DRGs system.

Advantages and Disadvantages of the DRGs Practice in Turkey

Considering the specific characteristics of health services and some other factors, in order to make the repayment of the provision of health services individually or socially by the health institutions in a correct and transparent manner; Many reimbursement methods continue to be used, such as "pay-per-service", "per-case payment", "daily payment", "pay per person", "global budget payment" and "salary payment" [7, 18] . Each of these methods is stated to have strengths and weaknesses $[15,18]$.

New reimbursement models are provided that provide data and information support to health-related decisions by enabling reduction of costs in hospitals, providing quality health services, providing transparency in the reimbursement system, and measuring individual and corporate performance $[7,19]$. In this context, as a reimbursement model DRGs, which was launched in 1983. DRGs system began to be implemented in Turkey, 2005 by Hacettepe University considering the scope of a project executive. The DRGs study, one of the sub-headings of the Hacettepe University Research Project (HUAP), was concluded in 2009 only 4 years after the start of the project $[20,21]$.

The main purpose of initiation to implementation of the DRGs system as reimbursement model in Turkey, the nature of the needs of individuals who need health services, quantity and, the provision of financial resources necessary to meet the severity and this need is to use them effectively and efficiently. In addition, the main purpose of the DRGs system is to provide the same rate of pricing and reimbursement of diseases and clinical cases with similar diagnosis and relative values [22].

DRGs system was launched with the aim to be effective reimbursement system in health services, transparent and efficient within the scope of a 4-year DRG project work was done in Turkey. During this four-year project, the Ministry of Finance (MoF), Ministry of Health $(\mathrm{MoH})$, Ministry of Labor and Social Security (MoLSS), Social Security Institution (SSI) and Hacettepe University (HU) it is stated that experience their importance for all stakeholders related issues in Turkey [23] .

DRGs system was piloted in Turkey, based on the example of the Australian DRGs model has been started in 2006. DRGs reimbursement system was used in conjunction with other reimbursement models in Turkey [20, 24, 25] . As reimbursement model Health Application Communique (HAC) is still used where determined the price of health services. HAC is issued by the Social Security Institution (SSI). Concurrently with the HAC, work on the DRGs reimbursement model is still in progress [20, 22, 24-28] .

To create a reliable, measurable, comparable and transparent reimbursement system, for health services delivered by health care providers DRGs system was implemented in Turkey. However, by focusing only on some objectives, it would be wrong to expect benefits from the DRGs system, and if it will be beneficial, it can be stated that many criteria should be evaluated together in order to achieve this benefit.

With regard to the issue of Turkey as a model of health care reimbursement system considering the advantages of using the DRGs system the following advantages can be listed $[2,7,14-16,18,19]$.

- Evaluating similar clinical cases with similar costs and making equal pricing for equal services accordingly;

- Accurate calculation of costs if products in health care institutions are correctly identified,

- Individual and institutional performance can be evaluated objectively if diseases with similar codes are weighted at similar rates,

- Transparency is ensured in the reimbursement system if products and outputs are correctly identified,

- Efficiency in resource allocation is ensured if the data obtained with the DRGs reimbursement system are analyzed correctly;

- If the DRGs repayment model is used without attempting to provide unnecessary or less service by benefiting from information asymmetry without taking into account the health care services provided to the physician and the hospital, the quality of the health services given will be increased.

- Efforts to provide health services with cost-benefit analyzes increase both technical efficiency and allocation efficiency, which constitutes an important objective of the DRGs system, 
- The weaknesses of other reimbursement models other than the DRGs system are eliminated and the strengths of the DRGs system are highlighted and quality, less costly and comparable health services are provided.

Turkey as a model in the health system reimbursement least as far as the advantages of using the DRGs system also referred to as the disadvantages. In this context, the following disadvantages can be listed in the DRGs system as a reimbursement model [2, 7, 14-16, 18, 19] .

- Failure to make repayments in a healthy way due to poorly defined codes,

- Missing or incorrect weighting of codes due to inadequate measurement of products in the hospital,

- The diversity of products and outputs due to the special features of health services and the possibility of taking place in the codes by making many coding accordingly,

- Arrange invoices with a high coding rate, incomplete coding, extra coding, or a different rate of return than coding, due to situations such as ile reverse information,, farklı moral hazard veya and, information asymmetry, in health services,

- Presence of fewer developments in the areas of expertise with lesser rate of return,

- Increased likelihood of not providing the necessary services with commercial concerns,

- Health services are seen only as coding and the biopsycho-social aspects of individuals are unlikely to be ignored.

When in the DRGs system as seen Turkey health service use as a reimbursement models both advantages as well as disadvantages could be especially some systemic and managerial (Weighting of the weights of the complex codes taking into account the difficulty of the product or output concerned, effective use of mechanisms such as decision support systems, clinical decision support systems, early warning systems, abandoning the evaluation of performance systems only through codes, the costs of the specified products or outputs are well Measures such as calculation and ensuring that physicians and hospitals do not experience a loss of rights from codes entered for these products or outputs) as precautions are not taken, the disadvantages of the DRGs system, may also be further than advantages.

\section{DISCUSSION}

Many reimbursement methods are used to provide health care services provided by health institutions individually or socially. DRGs reimbursement models as well, the need for provision of health services in the provision of the services offered around the world and is also a significant reimbursement system used in Turkey. In this context, in the light of the information obtained within the framework of the theoretical knowledge in this study, it will be tried to be based on the study with the findings obtained from the experimental studies on the subject.

According to the information obtained from the master's thesis named "Reimbursement system with DRGs and the attitudes of hospital managers towards this system" conducted by Kadiz in 2011, as reimbursement model DRGs system has been found to provide standardization and predictability of services provided by all stakeholders in health services. In the same study, it was found that physicians who are the main actors in the provision of health services are more interested in medical matters than financial issues [4] .

Within the scope of the DRGs system used in Germany, the costs related to the services are collected from the hospitals which are reliable for each year. In addition, since the relative values are not used in the hospitals in Germany, complicated health services are provided without interruption. Within the scope of the DRGs system in Germany, equal payment to the equal service of public and private sector employees has been ensured. Similar payments are made for similar services offered by public and private hospitals. Everyone, regardless of whether it is a general health insurance or individual insurance, pays equal price for equal service $[18]$.

With the use of the DRGs system in the United States of America (US), it was found that there was a $500 \%$ increase in daily surgical procedures. There was a decrease in hospital stay (from 10 days to 8.5 days). There is an increase in outpatient care and expenditures in all fields. Decrease in costs was determined. It was determined that physicians chose patients according to their disease status $[29,30]$.

With the use of the DRGs system as a reimbursement model in Austria and Australia, all stakeholders adopt the reimbursement model as a transparent and fair system and use the resources in hospitals more efficiently and effectively [31-33] .

With the DRGs system in Belgium and Denmark, the importance of health economics has attracted attention. Short stays in hospitals, after a while brought home care services. Economic efficiency is provided [32] .

With the use of the DRGs system in Finland and Italy, the length of stay in hospitals has been shortened, and the costs of the services provided have been reduced but the number of routine medical examinations has increased [32, 34].

In a study conducted in Italy, it was determined that hospital admissions increased during the day and those who applied to the hospital came for serious diseases. In a study conducted in United States of America, premature infants who were discharged from hospital were found to have increased hospitalization levels on the same day [35-37] .

\section{CONCLUSION}

As can be seen, the adoption of the DRGs system as a reimbursement model in health services in any country cannot provide transparency and fairness in a stand-alone reimbursement system. In this context, the system should be designed according to all possible handicaps of the system before the DRG systems are applied in general. When determining the DRGs as a reimbursement model, it should 
be decided whether the relative values for which diseases are used and whether the relevant diseases are appropriate for this site. One of the most important issues in the DRGs system is the process of determining costs clearly, accurately, objectively and up-to-date. This process should be determined not only by hospitals but by the participation of all stakeholders in health services. It can be stated that the use of DRGs system as a reimbursement model in health services can be achieved by supporting each other with integrated hospital information management systems and related guidance practices. As a model of integrated healthcare reimbursement system DRGs system will provide Turkey surely many benefits to health economics. However, considering the handicap in countries where use of the DRGs model to draw lessons for Turkey, will be applied as repayment model is also bringing out its strengths, which are the forefront of the DRGs system, go to way to eliminate the weaknesses of Turkey in health financing reforms and policies that are more healthy way may guarantee that execution It is believed.

\section{REFERENCES}

[1] Casto, A. B. and Layman, E. (2006). Principles Of Halthcare Reimbursement, American Health İnformation Manegement Assocation.Bakınız:library.ahima.org/xpedio/groups/public/ documents/ahima/bok1_030575.pdf Date of access: 01.27.2019

[2] Preston, A. M., Chua, W-F. and Neu, D. (1997). The Diagnosis-Related Group Prospective Payment System And The Problem Of The Government Of Ratıoning Health Care To The Elderly, Accounting, Organizations and Society, Vol. 22, No. 2, pp. 147-164, 1997.

[3] Gianino, M. M., Russo, R., Siliquini, R., Icardi, G. P., Fora, R. and Renga, G. (2006). Public and private in italian health care: trends and market quotas, Italian Journal of Public Health (IJPH), year 4, volume 3, number 3-4.

[4] Kadı, Y. (2011). "Hastanelerde DRG "ye Dayalı Ödeme Sistemi ve Bir Kamu Hastanesi Hekimlerinin Tutumu”, Dokuz Eylül Üniversitesi Sosyal Bilimler Enstitüsü İşletme Anabilim Dalı Hastane ve Sağlık Kuruluşları Yönetimi Programı Yüksek Lisans Tezi, 2011.

[5] Roberts, M. J., Hsiao, W., Reich, B., and Michael, R. (2009). "Sağlık Reformunun Doğru Yapılması", Baş Editör (çev.) Akdağ. R., Sağlık Bakanlı̆̆ı, 2009.

[6] Tengilimoğlu, D., Işık, O. and Akbolat, M. (2009). Sağlık İşletmeleri Yönetimi, Ankara, 2009.

[7] Hsiao, W. C., Sapolsky, H. M., Dunn, D. L. and Weiner, S.L. (1986). "Lessons of the New Jersey DRG Payment System", Health Affairs, Summer, Sayı: 5, s. 32-45.

[8] Preston, A. M., Cooper, D. J. and Coombs, R. (1992). Fabricating Budgets: A Study of the ProdCuction of Management Budgeting in the National Health Service, Accounting, Organizations and Society pp. 561-593.
[9] Gibbons, L. H. (1983). Diagnosis Related Groups (DRGs) and the Medicare Program:Implications for Medical Technology a technical memorandum. Washington: Superintendent of Documents. [10] Hopwood, A. G. and Tomkins, C. (1984). Issues in Public Sector Accounting.Philip Allan, s.247

[11] Badham, J. and Brandrup, J. (2000). Length of stay comparisons for private and public hospitals, Australian Health Review, Vol 23, No 3.

[12] Chua, W. F. and Degeling P., Interrogating an Accounting-Based Intervention on Three Axes: Instrumental, Moral and Aesthetic, Accounting, Organizations and Society (1993) pp. 291318.

[13] Laughlin, R. and Broadbent. J., (1993). Accounting and Law: Partners in the Juridihcation of the Public Sector in the UK? Critical Perspectives on Accounting, pp. 337-368.

[14] Preston, A. M., (1992). The Birth of Clinical Accounting: A Study of the Emergence and Transformations of Discourses on Costs and Practices of Accounting in U.S. Hospitals, Accounting, Organizations and Society), pp. 63-100.

[15] Covaleski, M. A., Dirsmith, M. and Michelman, J. E., (1993). An Institutional Theory Perspective on DRGs, Framework, Case Mix Accounting and Health Care Organizations, Accounting, Organizations and Society, pp. 65-80.

[16] Ayanoğlu, Y. and Beylik, U. (2014). Sağlık İşletmelerinde Geri Ödeme Modeli Olarak DRG: Kavramlar, Metodolojiler, Ülke Deneyimleri ve Karşılaştırmaları, Gazi kitapevi, Ankara.

[17] Cacace, M. and Schmid, A. (2009). The role of diagnosis related groups (DRGs) in healthcare system convergence, BMC Health Services Research 2009, 9(Suppl 1):A5 doi:10.1186/1472-6963-9-S1-A5.

[18] Street, A., Scheller-Kreinsen, D., Geissler, A., Busse, R. (2010). Determinants of Hospital Costs and Performance Variation: Methods, Models and Variables for the EuroDRG Project. Berlin: Universitätsverlag der Technischen Universität Berlin (working Papers in Health Policy and Management Volume 3).

[19] Narmanl, M., Ertong, G., Dikici, A., Soysal, E., Tümay, A. and Güngör, M. K. (2012). ” Ulusal Teşhis İlişkili Gruplar Sistemine Geçiş İçin Yol Haritası”, IX.Ulusal Tıp Bilişimi Kongresi, s.30.

[20] Fetter, R.B. (1991). Diagnosis Related Groups: Understanding Hospital Performance, Interfaces, 21(1), 1991, s. 6-26.

[21] Belek, İ. (2009). Sağlığın Politik Ekonomisi, Sosyal Devletin Çöküşü, İstanbul Yazılama Yayınları. 
[22] Hughes, W. E. and Pinch, T. (eds), (1987). The Sociological Construction of Technological Systems: New Developments in the Sociology and History of Technology (Cambridge, Mass: MIT Press,).

[23] TİG Uygulama Rehberi, (2011). https://

dosyamerkez.saglik.gov.tr/Eklenti/3621,tigkitapwebpdf.pdf?0, Date of access: 01. 30.2019.

[24] Kaya, N. (2008). Sağlık Yöneticilerinin Sağlık Hizmetleri Finansmanına ve Sunumuna Yönelik Görüşlerinin Değerlendirilmesi, Ankara: Başkent Üniversitesi, Sosyal Bilimler Enstitüsü

[25] Hacettepe Üniversitesi (2007). Sağllk Hizmetleri Finansman Yapısının Güçlendirilmesi ve Yeniden Yapılandırılması İçin Altyapı Geliştirilmesi Projesi, Rapor (E.1.6): Sağlık Hizmetlerinin Yönetilmesi ve Ödemelerinden Sorumlu Kamu Kurumlarında DRG Uygulamaları ile İlgili Politikaları Geliştirecek ve İzleyecek Birimlerin Oluşturulmasına Yönelik Öneri Raporu.

[26] Teşhis İlişkili Gruplar Bilgilendirme Rehberi. (2014). http://www.saglikturizmi.gov.tr/19-jci-akreditehastaneleri.html Date of access: 01. 30.2019.

[27] Euro DRG. (2018). http://cordis.europa.eu/projects/ rcn/89392_en.html, Date of access: 01. 30.2019.

[28] Tarcan, M. (2013). Hastanelerde Maliyet Hacim Kar Analizi. İçinde: M. Top (Edt.) Sağlık Kurumlarında Maliyet Yönetimi. Eskişehir: Anadolu Üniversitesi Açıköğretim Fakültesi. Anadolu Üniversitesi Yayın No: 2865, s. 177-203.

[29] Akar, Ç. (2002). Temel Finansal Kavramlar. İçinde: M. Çoşkun (Edt.) Sağlık Kurumlarında Finansal Yönetim. Eskişehir: Anadolu Üniversitesi Açıöörretim Fakültesi. Anadolu Üniversitesi yayın no. 1388, Açıöğretim Fakültesi yayın no. 753 , ss. 1-28.

[30] Özgülbaş, N. (2002). Sağlık ve Finansal Çevre. İçinde: M. Çoşkun (Edt.) Sağlık Kurumlarında Finansal Yönetim. Eskişehir: Anadolu Üniversitesi Açıöğretim Fakültesi. Anadolu Üniversitesi yayın no. 1388, Açıöğretim Fakültesi yayin no. 753 , ss. $28-40$.

[31] Mcguire, A. (2011). "Hastanelere Geri Ödeme, Rekabet ve Sonuç”, Türkiye Sağlık Hizmetlerinde Ödeme Yöntemleri Sempozyumu, Power Point Sunusu, Ankara, Şubat 2011.

[32] Shah, J. (2008). “Uluslararası TİG Çalışmaları”, TİG (Tanı İlişkili Gruplar) Bülteni, sayı 3.

[33] Marshall, R. P. (2008). “Avustralya/Viktorya Eyaletinde Uygulanan TİG’e (DRG) Dayalı Ödeme Sistemi”, TİG (Tanı İlişkili Gruplar) Bülteni, Sayı 2.
[34] HOPE Report (2006). "DRGs As a Financing Tool”, European Hospital and Healthcare Federation,Bakınız:http:// www.hope.be/05eventsandpublications/ docpublications/77_drg_report/77_drg_report_2006.pdf.

[35] Hagenbıchler, E. (2010). “The Austrian DRG System” Federal Ministry of Health, Radetzkystrasse 2.

[36] Mikkola, H. and Linna, M. (2002). "Diagnosis Related Groups (DRGs) In Finnish Hospital Care”, Revue Medical Assurance Maladie, Volume: 3, Number: 1 (37-43).

[37] Ersoy, Z. (2014). Geri Ödeme Modeli Olan Teşhis İlişkili Gruplar (TIG) ve Bu Model Üzerinde Sağlık Yöneticilerinin Görüşlerinin Değerlendirilmesi, Gazi Üniversitesi Sosyal Bilimler Enstitüsü, İşletme Anabilim Dalı Hastane İşletmeciliği Bilim Dalı, Yüksek Lisans Tezi, Ankara.

\section{AUTHOR BIOGRAPHY}

Haşim ÇAPAR Department of Health Management, Faculty of Health Sciences, Istanbul Sabahattin Zaim Univer-sity, Istanbul, Turkey 